УДК 619:616-071:616.61:636.38

(C) 2014

Цвіліховський М. І., доктор біологічних наук, професор, академік НААНУ, Локес-Крупка Т. П., аспірант

(Науковий керівник - доктор біологічних наук, професор, академік НААНУ М. І. Цвіліховський)

Національний університет біоресурсів і природокористування України

\title{
АКТИВНІСТЬ ФЕРМЕНТІВ СИРОВАТКИ КРОВІ ЗА ГЕПАТОЛІПІДОЗУ СВІЙСЬКИХ КОТІВ У ПРОЦЕСІ ЛІКУВАННЯ
}

\section{Рецензент - доктор ветеринарних наук, професор Б. П. Киричко}

Наведені результати дослідженнь свійських котів різного віку та статі, хворих на гепатоліпідоз, у прочесі лікування. Наведена схема лікування, щзо включає дієто- $i$ фармакотерапію. $У$ результаті комплексного лікування у котів встановлені позитивні зміни загального стану. Це підтверджують зміни біохімічного спектру крові тварин. Знизилася активність АлАТ $і$ АсАТ у сироватчі крові як у тварин першої, так і другої груп (I група - на 23,3 ma 20,6\%, II група - на 19,1 та 16,3 \% відповідно). Активність ЛФ у сироватці крові знизилася у тварин першої та другої груп на 24,8 і 19,2\% відповідно. Аналогічна тенденція спостерігалася й щзодо активності ГГТП, яка у сироватці крові котів першої групи знизилася на 25,4\%, а другої-на 28,4\%.

Ключові слова: коти, гепатоліпідоз, ферменти, лікування.

Постановка проблеми. Гепатоліпідоз у свійських котів розвивається внаслідок впливу різноманітних токсичних речовин, порушення функцій печінки та обмінних процесів. Лікування гепатоліпідозу у свійських котів має бути комплексним і поєднувати в собі низку напрямів. До того ж слід звернути увагу на те, що дана патологія супроводжується порушенням метаболізму в цілому.

Аналіз основних досліджень і публікацій, у яких започатковано розв'язання проблеми. Незважаючи на численні дослідження, патогенез даної хвороби залишається досконало не вивчений. Захворювання вважається первинним, але аналізуючи анамнез хвороби і проводячи детальну діагностику, нерідко виявляють обставини або хворобу, що супроводжуються порушенням апетиту у тварин $[1,5,6]$. Клінічно захворювання проявляється за накопичення тригліцеролів або нейтральних ліпідів більше ніж у $80 \%$ гепатоцитів [4].

Успіх лікування котів за гепатоліпідозу залежить від можливості забезпечення організму хворої тварини поживними речовинами, корекції обміну речовин (за допомогою рідинної та електролітної терапії, а також забезпечення необхід- ними мікроелементами та вітамінами) [3].

Метою нашої роботи було дослідити зміни активності окремих ферментів сироватки крові за гепатоліпідозу свійських котів у процесі лікування.

Для досягнення мети необхідно було вирішити наступне завдання: вивчити зміни активності АлАТ, АсАТ, ЛФ та ГГТП у процесі лікування свійських котів за гепатоліпідозу.

Матеріали і методи досліджень. Об'єктом дослідження були свійські коти різного віку та статі. Тварин досліджували за загальноприйнятою схемою. Котів без видимих клінічних ознак порушень обміну речовин та патології печінки використовували в якості контролю.

Базуючись на припиненні дії основного етіологічного фактора - незбалансованій годівлі першочергово застосовували жорстку дієтотерапію. Щоб не завдавати котам додаткового стресу внаслідок переходу виключно на натуральний корм, ми звертали увагу на те, чи утримувалася тварина раніше на натуральному кормі, чи то власники котів віддавали перевагу сухому корму. На цій основі свійських котів було поділено на дві групи: перша - тварини, які утримуються на сухих кормах і консервах промислового виробництва $(\mathrm{n}=28)$, друга - тварини, які утримуються на натуральному раціоні $(\mathrm{n}=19)$.

Для першої групи котів рекомендували сухий корм Royal Canin Obesity. Дозування корму визначали залежно від маси тіла тварин. Обов'язковою умовою для цієї групи тварин було чітке дозування корму та цілодобовий вільний доступ до води. Тварин другої групи утримували на раціоні, що включав куряче нежирне м'ясо, каші (вівсяна, гречана) та кисломолочні продукти з низьким відсотком жиру. Виключали смажені, жирні, пересолені корми, а також солодощі та борошняні вироби (макарони, хліб).

Для свійських котів обох груп застосовували порційну годівлю 3-4 рази на добу, у тяжких випадках - 5-6-разову. Тварин обох груп лікували за схемою, вказаною в таблиці 1. 
BETЕРИНАРНА МЕДИЦИНА

\section{1. Схема лікування хворих на гепатоліпідоз свійських котів}

\begin{tabular}{|c|c|c|c|}
\hline & «Тіопротектин» & «Гепаві-кел» & «Гепатовет» \\
\hline Доза, мл & 1,0 & 0,5 & $3-6$ \\
\hline Шлях введення & внутрішньом'язово & підшкірно & внутрішньо \\
\hline Кратність введення (на добу) & 2 & 1 & 3 \\
\hline $\begin{array}{c}\text { Тривалість застосування } \\
\text { (доби лікування, 3 ... по) }\end{array}$ & $1-14$ & $1-30$ & $15-30$ \\
\hline
\end{tabular}

2. Біохімічні показники сироватки крові після лікування гепатоліпідозу у свійських котів, М土m

\begin{tabular}{|c|c|c|c|c|c|}
\hline \multirow{3}{*}{ Показник } & \multirow{3}{*}{$\begin{array}{l}\text { Клінічно здо- } \\
\text { рові тварини } \\
(\mathrm{n}=19)\end{array}$} & \multicolumn{4}{|c|}{ Хворі тварини } \\
\hline & & \multicolumn{2}{|c|}{ на початку лікування } & \multicolumn{2}{|c|}{ після лікування } \\
\hline & & I група (n=28) & II група $(\mathrm{n}=19)$ & $\begin{array}{c}\begin{array}{c}\text { I група } \\
(\mathrm{n}=25)\end{array} \\
\end{array}$ & $\begin{array}{c}\text { II група } \\
(\mathrm{n}=16)\end{array}$ \\
\hline АлАТ, Од/л & $43,2 \pm 2,34$ & $75,2 \pm 2,79$ & $75,1 \pm 2,87$ & $57,6 \pm 1,93 *$ & $60,8 \pm 2,34 *$ \\
\hline АсАТ, Од/л & $31,4 \pm 1,82$ & $49,2 \pm 1,80$ & $49,2 \pm 2,34$ & $39,0 \pm 1,44^{*}$ & $41,2 \pm 1,73 * *$ \\
\hline ЛФ, Од/л & $53,7 \pm 3,23$ & $86,6 \pm 1,99$ & $83,7 \pm 3,01$ & $65,1 \pm 1,51^{*}$ & $67,6 \pm 1,60 *$ \\
\hline ГГТП, Од/л & $6,3 \pm 0,37$ & $11,8 \pm 0,64$ & $13,1 \pm 0,78$ & $8,8 \pm 0,49 *$ & $9,4 \pm 0,68 * *$ \\
\hline
\end{tabular}

Примітка: * - p<0,001 вірогідно, порівняно з даними на початку лікування котів; ** - p<0,01 вірогідно, порівняно з даними на початку лікування котів

Курс лікування котів тривав один місяць із наступним дотриманням дієтотерапії та періодичної підтримуючої терапії. Дозування всіх лікувальних препаратів котам із ожирінням проводили 3 розрахунку їх маси тіла без жирових відкладань, аби запобігти передозування [2].

Результати досліджень. Фармакологічний ефект Тіопротектину обумовлений антиоксидантними, мембрано-стабілізуючими та імуномодулюючими властивостями. Зважаючи на значну роль печінки у депонуванні та активації водорозчинних вітамінів, свійським котам, хворим на гепатоліпідоз, «Гепаві-кел» задавали у подвійних дозах, рекомендованих для здорових тварин даного виду. На третій тиждень лікування замість «Тіопротектину» до схеми лікування вводили рослинний гепатопротектор «Гепатовет» для свійських котів: він зупиняє переродження гепатоцитів та підвищує ферментативну активність печінки в цілому. Слід зазначити його дію на обмін ліпідів, що проявляється у зниженні концентрації холестеролу в крові та підвищенні вмісту фосфоліпідів.

У результаті комплексного лікування вже через тиждень інтенсивної терапії котів були встановлені позитивні зміни у клінічному стані котів обох груп. Біохімічний спектр крові котів у процесі лікування зазнав певних змін (табл. 2).
Завдяки активній фармакотерапії котів гіперферментемія стала менш значною. Так, зменшилась активність АлАТ і АсАТ у сироватці крові як у тварин першої, так і другої груп (I група на 23,3 та $20,6 \%$, II група - на 19,1 та $16,3 \%$, відповідно). Аланінотрансфераза, що локалізується в цитоплазмі, легко проникає через мембрану, тоді як аспартатамінотрансфераза, що міститься в органелах, всмоктується у кров повільніше. Зниження активності цих ферментів свідчить про припинення руйнування паренхіми печінки й поступове відновлення ії функцій навіть на мітохондріальному рівні.

Лужна фосфатаза локалізуєтсья у плазматичній мембрані епітелію жовчовивідних шляхів і гепатоцитів, а гамаглутамілтранспептидаза - в епітелії внутрішньопечінкових жовчних протоків. Підвищення активності цих ферментів у сироватці крові хворих на гепатоліпідоз котів $\epsilon$ свідченням розвитку холестазу в жовчовидільних шляхах. Внаслідок лікування котів активність ЛФ у сироватці їх крові знизилась у тварин першої та другої груп на 24,8 та 19,2 \% відповідно. Така ж тенденція спостерігалася й щодо активності ГГТП, яка у сироватці крові котів першої групи знизилася на $25,4 \%$, а другої - на $28,4 \%$. 


\section{ВЕТЕРИНАРНА МЕДИЦИНА}

Висновок. Застосування жорсткої дієто- та фармакотерапії («Тіопротектин», «Гепаві-кел» та «Гепатовет» для котів) сприяє нормалізації актив-

\section{БІБЛІОГРФІЯ}

1. Болезни собак и кошек. Комплексная диагностика и терапия болезней собак и кошек: учеб. пособие / [Т. К. Донская и др.]; под ред. С. В. Старченкова. - СПб. : Спец. литература, 2006. $-655 \mathrm{c}$.

2. Диез $M$. Бальная оценка упитанности кошек и собак / М. Диез // Focus Waltham. - 2006. - №1. - C. 39-40.

3. Кирк $P$. Современный курс ветеринарной медицины Кирка / Р. Кирк, Д. Бонагура [пер. с англ.] - М. : ООО «Аквариум принт», 2005. $1376 \mathrm{c}$.

4. Ниманд Ханс Г., Сутер Петер Ф. Болезни ності ферментних систем і відновленню функціональних властивостей печінки у свійських котів за гепатоліпідозу.

собак. Практическое руководство для ветеринарных врачей (организция ветеринарной клиники, обследование, диагностика заболеваний, лечение), 8 изд.; перев. с нем., 2-е изд. - М. : Аквариум, 2001. - 816 с.

5. Armstrong P. J. Hepatic lipidosis in cats / P. J. Armstrong, G. Blanchard // Vet. Clin. North. Am. Small Anim. Pract. - 2009. - V. 39, № 5. P. 599-616.

6. Taboada J. Approach to the icteric cat. In JR August. Ed., Consultations in Feline Internal Medicine, 4th ed., Philadelphia: WB Saunders. 2001. - P. 87-90. 